DOI https://doi.org/10.30525/978-9934-26-180-0-7

\title{
МЕНТАЛЬНІ АСПЕКТИ РЕЦЕПЦІЇ ОСОБИСТОСТІ I ТВОРЧОСТІ А. ЧЕХОВА УКРАЇНСЬКИМИ ПИСЬМЕННИКАМИ ПЕРШОЇ ТРЕТИНИ ХХ СТ.
}

\author{
Борбунюк В. O. \\ кандидат філологічних наук, доцент, \\ дочент кафедри педагогіки, української та іноземної філології \\ Харківська державна академія дизайну і мистеитвв \\ м. Харків, Україна
}

Вивчення уявлень і оціночних суджень про культуру, мову і ментальність певного народу в літературі іншого народу, - одне з актуальних завдань сучасного літературознавства. Такі дослідження використовують імагологічний метод, яким послуговуються у літературознавстві для інтерпретації семантики феномена культурного, національного або етнічно «чужого», що проявляється у художніх текстах. Найбільш значущою для імагології $є$ категорія ментального образу. Інша культура у процесі сприйняття (перцепції) стає «ментальним продуктом» [4, с. 116], який перетворюється на рецептивний, прийнятний і засвоєний ментальний образ. Імагологія не тільки розкриває образ «іншого/чужого», але також характеризує і самого суб'єкта сприйняття, тобто, через аналіз «чужого» відображає і власну, «свою» систему цінностей.

Як справедливо зазначено, «слов'янські культури - доволі близькі, та водночас відмінні - отримують від взаємного спілкування надзвичайно багато: не тільки пізнають себе, найменші дрібниці своєї ідентичності, а й сприймають, розуміють і «одомашнюють» Іншого» [3, с. 218]. Сприйняття феноменів мистецтва крізь призму національної ідентичності, притаманне першій третині XX століття, виявляло авторів, особистості і творчості яких були загальними об'єктами художньої рецепції для багатьох національних літератур, незважаючи на географічні і політичні кордони. До таких прецедентних авторів, безсумнівно, належить А. Чехов.

У витоків сприйняття чеховського феномену і трансформації його образу із категорій «Чужий»/«Інший» на «Свій» була діяльність подружжя Грушевських, пов'язана із публікацією чеховських творів українською мовою у часописі «Літературно-науковий вістник». Спочатку М. Грушевський-критик осмислює творчість А. Чехов як представника «чужої літератури». У 1898 року у четвертому томі «Літературнонаукового вістника» він дає розлогий коментар чеховських здобутків, 
розмістивши у розділі «Із чужих літератур» розвідку під назвою «Новини російської літератури: Л.Толстой; Чехов; Боборикін; Мамін-Сибиряк і інші «сибиряки»; Потапенко; Микулич; Горкій; ювілей Бєлінського» [2]. Однак семантика категорії «Чужий» стосовно А. Чехова тяжіє, за М. Грушевським, більше до категорії «Інший». Його розуміння А. Чехова свідчить про зв'язок, діалог культур і не має негативного смислу.

Висловлює М. Грушевський на адресу А. Чехова і свої невдоволення. В оповіданні «Человек в футляре», вказує критик, він «устами персонажа, i то досить позитивного, зачепив по дорозі наших компатріотів: там виведена «хохлушка» з Гадяцького повіту з різними смішними прикметами, і по дорозі «влетіло» хохлушкам взагалі» [2, с. 142]. «Я думаю, закінчує М.Грушевський, - що Чехов не позволив би цьому своєму персонажу сказати щось подібне за польок, фінок і т.д., а 3 «хохлами» які ж церемонії!» [2, с. 142]. Ця щира, непідробна (i, звичайно, несправедлива) образа на А.Чехова в особі його персонажа, висловлена всупереч жанру публікації не в академічній формі, а в приватно-інтимній, свідчила насправді не просто про визнання таланту письменника, а й сприйняття його як близької людини. Саме так відреагує М. Грушевський на звістку про смерть письменника, відчувши «щирий біль як по утраті сердечного приятеля, що ділився 3 ними сумними або меланхолійними спостереженнями над цим повним сумних конфліктів і гірких абсурдів світом» [1, с. 114]. Таким чином, простежується еволюція індивідуального бачення критика: чужий - інший - свій.

Творчі візії А. Чехова українськими письменниками та критиками віддзеркалюють як особистості авторів, так і прецедентні культурні константи суспільної свідомості. Так, зважаючи на те, що Леся Українка поставить А. Чехова в один ряд 3 відомими західноєвропейськими письменниками і драматургами, А. Чехов осмислюється нею як «Інший»: «Ібсен і Б'єрнстьєрн, наприклад, символісти, але не декаденти, a, наприклад, Мапассан і Чехов по настрою і філософії декаденти, але н е символісти» [8, с. 31]. Пізніше у листах письменниці з'явиться апеляція до чеховських персонажів. В одному із листів до Г. Хоткевича від 7 лютого 1907 р. Леся Українка говорить про свою сім'ю: «<..> Родина наша в розброді: мама в Полтаві $<\ldots>$, батько на Волині, а ми, «три сестри», тут (Микось живе окремо)» [8, с. 179]. Чеховські персонажі для української письменниці знакові і сприймаються як імпульс до розуміння самої себе.

Для сприйняття А. Чехова та чеховського доробку українськими письменниками 1920-1930-х років теж характерні всі три категорії імагології. Аналіз епістолярію М. Куліша свідчить, що для цього 
письменника А. Чехов скоріше «Свій» чи «Близький». Генезою такого сприйняття стало самоусвідомлення себе у колі визнаних майстрів літератури. У 1925 році молодий український автор отримує офіційне запрошення стати членом Московського т-ва драматичних письменників та композиторів: «Я було завагався, але уповноважений довів мені, що це діло грошей не коштує, а навпаки... і що власне він дивується, як мене i через що саме запрошено (мовляв, така велика честь: Луначарський, Островський, Чехов - члени цього Т[оварист]ва). Тоді я згодився, бо одцуратись було совісно. Як же: покійні Островські, Чехови та інші корифеї. Гарненько подякував за «честь» і згоду дав» [5, с. 528]. Після цієї згоди М. Куліш зауважує, що «товаришем став покійного Островського» і «близько» стоїть «до корифеїв (!)» [5, с. 528].

Чеховська творчість дає імпульс до розуміння самого себе чи товаришів по перу. В одному із листів періоду работи над «Комуною в степах» М. Куліш апелює до чеховської символіки із «Вишневого саду»: «Я приеду в субботу или воскресенье, если только не подымется над головой какой-нибудь «топор», который перерубит моё решение. Топор этот - непредвиденные обстоятельства. Но, надеюсь, что их не будет» [5, с. 623]. У порівнянні з А. Чеховим сприймається М. Хвильовий: «Щодо Хвильового, то певної сталої оцінки я не можу поки що дати. Він ще не витанцювався. Боюсь, щоб з нього не вийшов співець останнього вечора: Чехов + шматочок революції» (із листа до І. Дніпровського від 12.08.1924) [5, с. 504]. Але для самого М. Хвильового, у чиїй творчості, на думку М. Куліша, «світиться Москва» [5, с. 507], А. Чехов - «Чужий». На початку 1930-років у найтяжчий період свого творчого життя: недовіра партії, заборона постановок М. Куліш хотів переїхати із Харкова до Москви: «Думку маю і намір приїхати до Москви і пожити тут місяць-два, а потім знову місяць. Багато цікавого в театральній та літературній Москві. Може, й до літпраці охота появиться» [5, с. 646]. 3 цього приводу М. Хвильовий саркастично зауважив: «Ну що ж. - В Москву! В Москву! - закричали три сестри Чехова» [Цит. по: 7, с. 9].

Для Я. Мамонтова А. Чехов - «Інший», його сприйняття А. Чехова балансує між протилежним (абсолютно чужий) і тотожним (свій). Чеховська творчість сприймається як школа театральної майстерності: «... було б дивно, якби радянський драматург учився на творах Шекспіра, Мольєра, Островського і не міг нічого навчитися у А. Чехова. Адже А. Чехов був письменником-реалістом, і його творчість зовсім не подібна до творчості письменників-символістів його доби <...> (Л. Андрєєва, Ф. Сологуба й ін.)» [6, с. 100]. Рецепція А. Чехова Я. Мамонтовим репрезентує офіційну точку зору 1930 -х років, віддзеркалюючи суперечки 
про суспільне значення творчості А. Чехова 3 їх коливаннями від прохолодно-стриманих відгуків до відверто захоплених і навпаки.

Для В. Петрова (Домонтовича) А. Чехов апріорі «Свій». У мемуарах Юрія Шевельова зафіксоване його самоуподібнення: «А йому було байдуже, де друкуватися. <..> Домонтович заявив <..> він пише на рік коло тридцятьох аркушів і мусить їх десь друкувати. <... - Може, це цинічно, - сказав він, - але я скажу словами Чехова: Мені все одно, де друкуватися, хоч на підвіконні» [9, с. 157].

Для українських літераторів А.Чехов - критерій культурної значущості, сповідування творчих і життєвих принципів якого важливіше за частотність безпосередніх апеляцій до його імені. Образ А. Чехова, пройшовши через сприйняття українського письменницького середовища першої третини XX ст., став міцно укоріненим ментальним образом. На формування образу мав безпосередній вплив історико-культурний контекст, до якого належав реципієнт, через що оціночні уявлення коливались між «Чужий» або «Інший», бо представник чужої літератури чи іншої доби, та «Свій», духовно чи типологічно близький. Чеховський образ і творчий доробок, засвоюючись національною культурою, сприяли виявленню і пізнанню власного, національного.

\section{Література:}

1. Грушевський М. Антін Чехов, некролог. Літературно-науковий вістник. T. XXVII. Львів : Наукове товариство імені Шевченка, 1904. C. $114-117$.

2. Грушевський М. Новини російської літератури: Л.Толстой; Чехов; Боборикін; Мамін Сибиряк і інші «сибиряки»; Потапенко; Микулич; Горкій; ювілей Бєлінського. Літературно-науковий вістник. T. IV. Львів : Наукове товариство імені Шевченка, 1898. С. 134-150.

3. Забіяка І.В. Імагологічний аспект вивчення сучасної чеської та української літератур. Компаративні дослідження слов'янських мов i літератур. 2013. Випуск 21. С. 213-219.

4. Козлова А.А. Имагологический метод в исследованиях литературы и культуры. Обсерватория культурыл. 2015. № 3 С. 114-118.

URL: https://doi.org/10.25281/2072-3156-2015-0-3-114-118

5. Куліш М.Г. Твори: В 2 т. К.: Дніпро, 1990. Т. 2: П’єси, статті, виступи, документи, листи, спогади про письменника.

6. Мамонтов Я. Драматургія А. Чехова // За марксо-ленінську критику. 1935. № 4. С. 89-104. 